\title{
Spectrophotometric Assay of Phenylephrine hydrochloride in Pharmaceutical Formulation with Alizarin Red sulphonate in Aqueous Solution
}

\author{
T.S. Al-Ghabsha A.M.S. Al-Delymi \\ Department of Chemistry / College of Education
}

Mosul University

الخلاصة

تم تطوير طريقة طيفية بسيطة وسريعة وحساسة لتقدير الفينيل فرين هايدروكلوريد ـ تعتمد

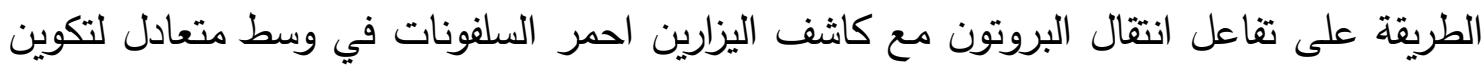
ناتج ذي لون بنفجي ذائب في الماء يقاس اقصى امتصاص لله عند طول موجي 530 نانوميتر وبامتصاصية مولارية 14320 لتر.مول -1.سم-1 وكان قانون بير ينطبق ضمن مدى التراكيز

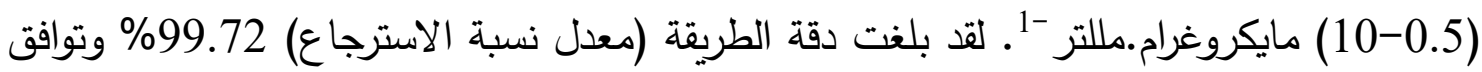

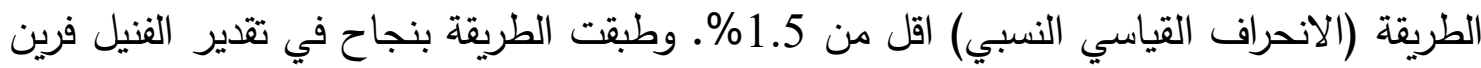

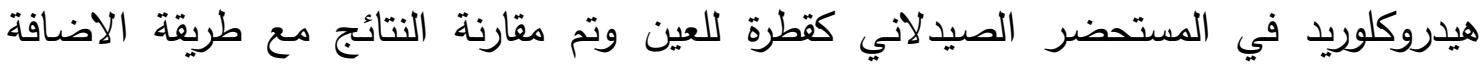

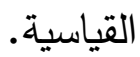

\section{ABSTRACT}

A simple, rapid and sensitive spectrophotometric method for the determination of phenylephrine hydrochloride was developed. The method is based on the proton transfer reaction with alizarin red sulphonate in aqueous neutral solution to form a violet product showing a maximum absorbance at $530 \mathrm{~nm}$ with molar absorptivity of $143201 . \mathrm{mol}^{-}$ ${ }^{1} . \mathrm{cm}^{-1}$. The method is obeyed Beer's law over the concentration range (0.5-10) $\mu \mathrm{g} \cdot \mathrm{ml}^{-1}$. The accuracy (average recovery) of the method is $99.72 \%$ and the precision (RSD) of the method is less than $1.5 \%$.

The method was successfully applied for the determination of phenylephrine hydrochloride in pharmaceutical formulation as eye drops and the results were in good agreement with the standard addition procedure.

\section{INTRODUCTION}

Phenylphrine(pp) is a decongestant has the following chemical structure ${ }^{(1)}$.

Presented at the second conference on Chemistry, University of Mosul, college of Education, 17-18 Novamber-2013. 


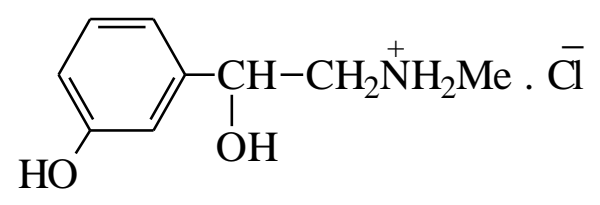

M.Wt. $=203$ mole

It works by constricting blood vessels (veins and arteries) . Constriction of blood vessels in the sinus, nose and chest allows drainage of these areas, which decreases congestion. Constriction of blood vessels also affects blood pressure. When taken by mouth, pp is used to treat congestion associated with allergies, hay fever, sinus irritation and the common cold . when used by injection pp is used to maintain adequate blood pressure and to treat certain types of irregular heartbeats ${ }^{(2-4)}$.

A spectrophotometric determination of $\mathrm{pp}$ in pharmaceutical preparation via oxidative coupling reaction with 4-amino antipyrine in the presence of sodium periodate, the absorbance of colored compound was measured at $500 \mathrm{~nm}^{(5)}$.

Spectrophotometric determination of $\mathrm{pp}$ hydrochloride in pharmaceuticals by flow injection analysis exploiting the reaction with potassium ferricyanide and 4-aminoantipyrine was developed. The red product shows maximum absorption at $500 \mathrm{~nm}^{(6)}$. $\mathrm{n}-\pi$ CT-complex formation reaction has been used for the determination of $\mathrm{pp}$ spectrophotmetrically with picric acid and m-dinitrobenzene as $\pi$ acceptors $^{(7)}$. A new spectrophotometric method is proposed for determination of PP. The method is based on the coupling of 4aminoantipyrine with PP to give a new ligand that reacts with copper (II) at $\mathrm{pH} 9$ to give an intense red colored chelate at $480 \mathrm{~nm}{ }^{(8)}$. pp has been determined by high performance liquid chromatography in human serum using column switching with fluorescence detection ${ }^{(9)}$, coloumetric detection $^{(10)}$, in capsules with UV detection at $215 \mathrm{~nm}^{(11)}$.

In this work alizarin red sulphonate reagent was used for the spectrophotometric determination of phenylphrine via proton transfer reaction in aqueous solution.

\section{EXPERIMENTAL}

\section{Apparatus}

A Shimadzu UV-210 A digital double beam spectrophotometer with $1 \mathrm{~cm}$ matched quartz cells was used for all spectral and absorbance measurements.

\section{Reagents}

pp hydrochloride and alizarin red sulphonate (ARS) used where from BDH company . All other chemicals used were of analytical-reagent grade. Distilled water was used for the preparations of all solutions except 
ARS solution was prepared in absolute ethanol, pp hydrochloride was dissolved in $5 \mathrm{ml}$ of ethanol then completed with distilled water.

\section{Solutions}

pp hydrochloride: $100 \mu \mathrm{g} \cdot \mathrm{ml}^{-1}$ of the pure drug was freshly prepared by dissolving $0.01 \mathrm{~g}$ in $100 \mathrm{ml}$ distilled water. This solution is protected from sun light and used as a standard solution for the analytical purposes. ARS: $1 \times 10^{-3} \mathrm{M}$ was prepared by dissolving $0.0856 \mathrm{gm}$ in $250 \mathrm{ml}$ of absolute ethanol. This solution was kept in brown bottle and was stable for, at least, one month.

\section{Procedure}

To a series of $10 \mathrm{ml}$ calibrated flasks, transfer an increasing volumes of pp hydrochloride working standard solution $\left(100 \mu \mathrm{g} \cdot \mathrm{ml}^{-1}\right)$ to cover the range (0.5-10) $\mu \mathrm{g} \cdot \mathrm{ml}^{-1}$ in final dilution. Add $2 \mathrm{ml}$ of $1 \times 10^{-3} \mathrm{M}$ ARS. Dilute the solution to the mark with distilled water, stopper the flasks and shake well, then allow the reaction mixtures to stand for $5 \mathrm{~min}$. at room temperature . The absorbance is measured at $530 \mathrm{~nm}$ against the reagent blank, using $1 \mathrm{~cm}$ cells.

\section{Assay procedure for phenylephrine hydrochloride drops :}

Three droppers of pp hydrochloride $(50 \mathrm{mg})$ marked by Sina Darou Tehran-Iran were mixed well then an equivalent volume to half dropper was taken and diluted with distilled water and completed to the mark in a $250 \mathrm{ml}$ volumetric flask, then different volumes used from this solution containing the concentration range $(0.5-10) \mu \mathrm{g} \cdot \mathrm{ml}^{-1}$. After that, following the procedure described above .

\section{RESULTS AND DISCUSSION}

\section{Absorption spectra}

pp hydrochloride was reacted with ARS to produce a violet coloured proton transfer product with a maximum absorption at $530 \mathrm{~nm}$ while the reagent blank shows low absorption at this wavelength (Fig. 1).

\section{Optimization of conditions}

\section{Effect of buffer solution}

The $\mathrm{pH}$ of the pure drug solution was 8.0 , And the final $\mathrm{pH}$ after the addition of $2 \mathrm{ml}$ of ARS was 7.0, therefore different buffers of $\mathrm{pH} 7.0$ were prepared such as borate, carbonate, acetate and phosphate. It was found that these buffers show decrease in the color intensity therefore the reaction was carried on a neutral medium (Table 1).

Table (1): Effect of buffer on the color intensity of product

\begin{tabular}{|l|l|l|l|l|l|}
\hline $\begin{array}{l}\text { Buffer solutions } \\
(\mathrm{pH} 7.0)\end{array}$ & Borate & Carbonate & Acetate & Phosphate & Without \\
\hline Absorbance & 0.021 & 0.007 & 0.030 & 0.024 & 0.321 \\
\hline
\end{tabular}




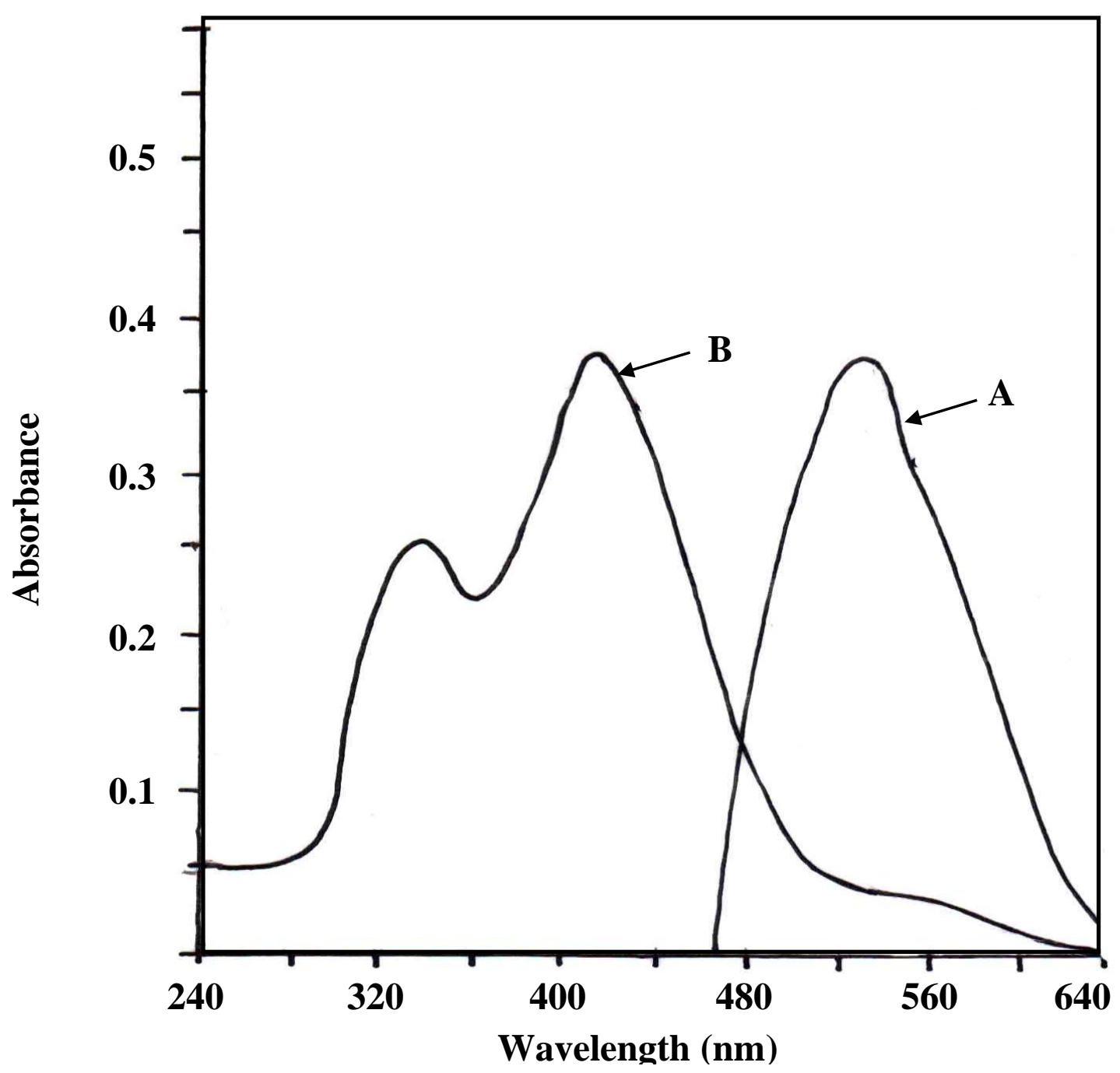

Figure (1): Absorption spectra of A: pp hydrochloride $\left(4 \mu \mathrm{g} \cdot \mathrm{ml}^{-1}\right)-\mathrm{ARS}\left(1 \times 10^{-3} \mathrm{M}\right)$ product versus reagent blank and B: Reagent blank versus distilled water at the optimum conditions

\section{Effect of temperature and reaction time}

The reaction time was determined by following the color development at room temperature and in thermostatically controlled water-bath adjusted at 0,40 and $50{ }^{\circ} \mathrm{C}$. The absorbance was measured at 10 mins. intervals against reagent blank treated similarly. It was observed that the colored product absorbance reached maximum after 5 mins. at room temperature and remained constant for 115 mins., whereas the absorbance decreased slowly thereafter. Hence room temperature and reaction time 5 mins., were chosen for color development (Table 2). 
Spectrophotometric Assay of Phenylephrine hydrochloride in ....

Table (2): Effect of temperature and reaction time

\begin{tabular}{|c|c|c|c|c|c|c|c|c|c|c|c|}
\hline \multirow{2}{*}{$\begin{array}{c}\text { Temp. } \\
\left({ }^{\circ} \mathbf{C}\right)\end{array}$} & \multicolumn{10}{|c|}{ Absorbance } \\
\cline { 2 - 13 } & 5 & 10 & 20 & 30 & 40 & 50 & 60 & 90 & 100 & 120 & 130 \\
\hline 0 & 0.315 & 0.316 & 0.316 & 0.317 & 0.320 & 0.315 & 0.315 & 0.314 & 0.312 & 0.314 & 0.314 \\
\hline RT & 0.350 & 0.318 & 0.350 & 0.349 & 0.350 & 0.348 & 0.350 & 0.350 & 0.350 & 0.350 & 0.345 \\
\hline 40 & 0.318 & 0.318 & 0.318 & 0.320 & 0.320 & 0.322 & 0.325 & 0.330 & 0.330 & 0.325 & 0.325 \\
\hline 50 & 0.318 & 0.318 & 0.322 & 0.326 & 0.327 & 0.333 & 0.332 & 0.330 & 0.330 & 0.325 & 0.325 \\
\hline
\end{tabular}

\section{Effect of ARS reagent concentration}

The effect of different ARS concentrations on the absorbance of colored solution containing $4 \mu \mathrm{g} \cdot \mathrm{ml}^{-1} \mathrm{pp}$ hydrochloride was studied, $2 \mathrm{ml}$ of $1 \times 10^{-3} \mathrm{M}$ ARS, give the maximum absorbance of the reaction product, therefore, this concentration was used in all subsequent work (Table 3).

Table (3): Effect of ARS concentration

\begin{tabular}{|c|c|c|c|c|c|}
\hline $\begin{array}{c}\text { ARS solution } 1 \times 10^{-3} \\
\mathrm{M}(\mathrm{ml})\end{array}$ & 1 & 1.5 & 2 & 2.5 & 3 \\
\hline Absorbance & 0.285 & 0.298 & 0.321 & 0.293 & 0.290 \\
\hline
\end{tabular}

\section{Effect of surfactant}

The effect of different types of surfactants were used for the improvement of the absorption intensity by two orders of reagents addition .The results shown in Table (4) confirm that there is no improvement in the color intensity of the product, therefore they were excluded.

Table (4): Effect of surfactant

\begin{tabular}{|c|c|c|c|c|c|c|}
\hline \multirow{2}{*}{$\begin{array}{c}\text { Surfactant } \\
0.1 \%\end{array}$} & \multicolumn{6}{|c|}{ Absorbance / ml } \\
\hline & Order & Without & 0.5 & 1 & 2 & 3 \\
\hline \multirow{2}{*}{ Tween $80^{*}$} & I & \multirow{6}{*}{0.321} & 0.320 & 0.318 & 0.319 & 0.319 \\
\hline & II & & 0.317 & 0.318 & 0.317 & 0.317 \\
\hline \multirow{2}{*}{$\mathrm{CPC}$} & I & & 0.320 & 0.320 & 0.318 & 0.319 \\
\hline & II & & 0.319 & 0.316 & 0.316 & 0.317 \\
\hline \multirow{2}{*}{ SDS } & I & & 0.318 & 0.318 & 0.317 & 0.317 \\
\hline & II & & 0.318 & 0.316 & 0.316 & 0.317 \\
\hline
\end{tabular}

$* 1 \%$

I pp + ARS + surfactant

II $p p+$ surfactant + ARS

\section{Analytical data}

Under the optimized experimental conditions, a linear relation between the absorbance and the concentration of $p p$ hydrochloride was observed cover the concentration range (0.5-10) $\mu \mathrm{g} \cdot \mathrm{ml}^{-1}$ (Fig. 2) with correlation coefficient of 0.9998 and intercept of 0.0386 . A negative deviation from Beer's law was observed at higher concentrations of $\mathrm{pp}$ hydrochloride. The molar absorptivity was $143201 . \mathrm{mol}^{-1} . \mathrm{cm}^{-1}$. 


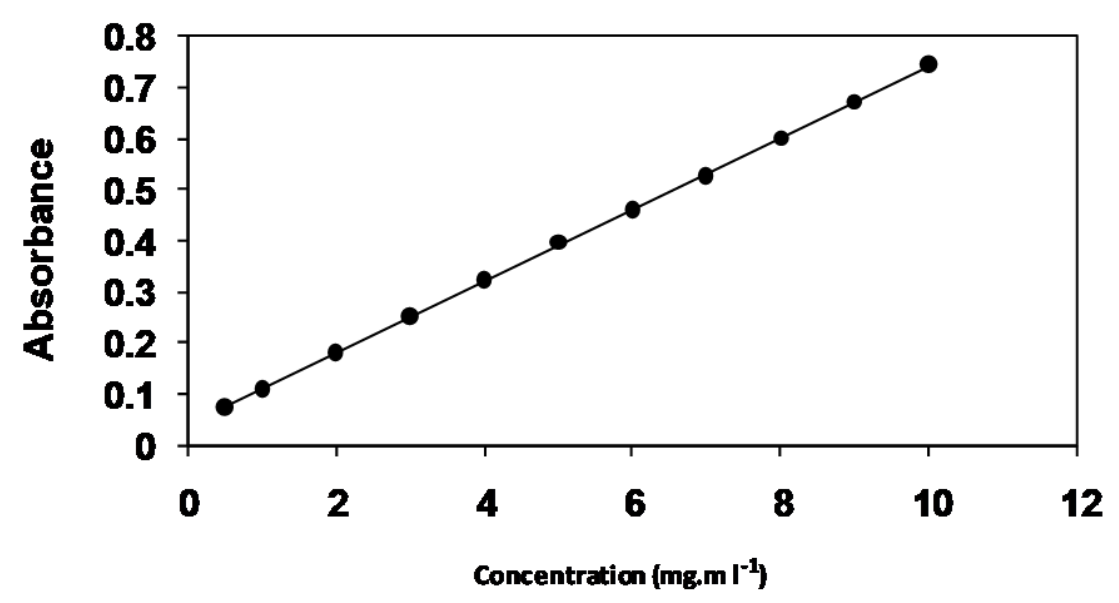

Figure (2): Calibration graph of pp hydrochloride

\section{Accuracy and precision}

To determine the accuracy and precision of the method, pp hydrochloride was determined at three different concentrations of six replicates. The results shown in table (5) referring a satisfactory precision and accuracy.

Table (5): Accuracy and precision of the proposed method

\begin{tabular}{|c|c|c|c|}
\hline $\begin{array}{c}\text { Amount of pp } \\
\text { hydrochloride taken } \\
\mu \mathrm{g} \cdot \mathrm{ml}^{-1}\end{array}$ & Recovery*\% & $\begin{array}{c}\text { Average } \\
\text { recovery \% }\end{array}$ & $\begin{array}{c}\text { Relative standard } \\
\text { deviation* (RSD\%) }\end{array}$ \\
\hline 4 & 99.07 & \multirow{2}{*}{$99.72 \%$} & 1.13 \\
\hline 5 & 100.76 & & 0.61 \\
\hline 6 & 99.35 & & 0.52 \\
\hline
\end{tabular}

\section{Nature of product and reaction mechanism}

The stiochiometry of the reaction between the drug and ARS was investigated using job's method ${ }^{(12)}$, with using equimolar solutions of each $\left(1 \times 10^{-3} \mathrm{M}\right)$. It was found that PP forms a product with ARS in the ratio of $1: 1$ as it is evident in figure 3 .

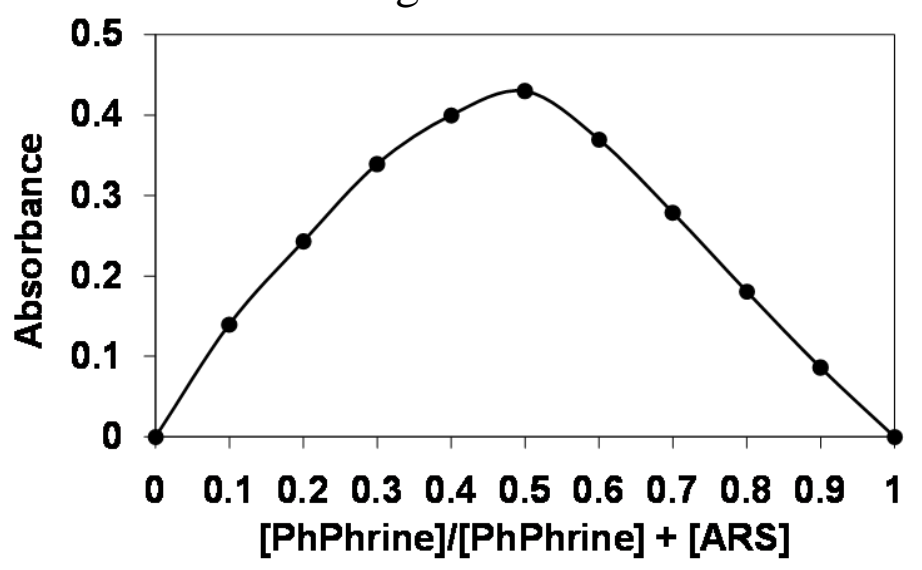

Figure (3): Job's method for pp hydrochloride-ARS product 
The formation of the product may be occur as follows ${ }^{(13)}$ :<smiles></smiles><smiles>[Y16][NH2+]CC(O)c1cccc(O)c1</smiles>

The stability constant of the product was estimated and found to be $3.71 \times 10^{5} 1 . \mathrm{mol}^{-1}$.

\section{Analytical application}

The proposed method was applied to the determination of $\mathrm{pp}$ hydrochloride in pharmaceutical eye drops. Good recovery was obtained and the results were compared with the standard addition method (Fig. 4 and Table 6).

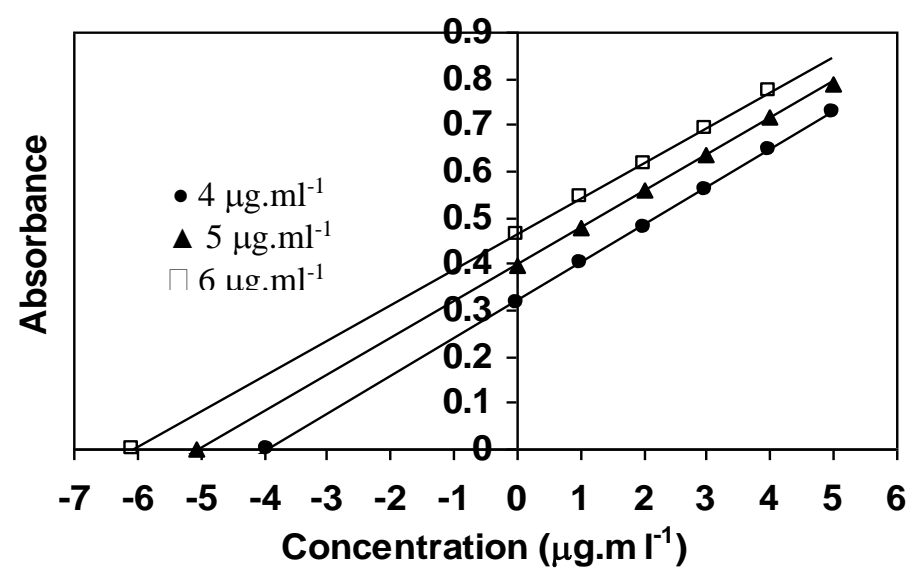

Figure (4): Standard addition graphs of pp hydrochloride in pharmaceutical formulation 
Table (6): Assay of pp hydrochloride in eye drops

\begin{tabular}{|c|c|c|c|c|c|}
\hline \multirow[b]{2}{*}{$\begin{array}{c}\text { Pharmaceutical } \\
\text { preparation }\end{array}$} & \multirow{2}{*}{$\begin{array}{l}\text { Cetified } \\
\text { value } \\
\text { mg }\end{array}$} & \multicolumn{2}{|c|}{$\begin{array}{l}\text { Drug content (mg) } \\
\text { found by }\end{array}$} & \multicolumn{2}{|c|}{ Recovery $^{*}(\%)$ of } \\
\hline & & $\begin{array}{c}\text { Direct } \\
\text { ARS } \\
\text { method }\end{array}$ & $\begin{array}{l}\text { Standard } \\
\text { addition } \\
\text { method } \\
\end{array}$ & $\begin{array}{c}\text { Direct } \\
\text { ARS } \\
\text { method }\end{array}$ & $\begin{array}{c}\text { Standard } \\
\text { addition } \\
\text { method } \\
\end{array}$ \\
\hline $\begin{array}{l}\text { Phenylephrine } \\
\text { hydrochloride } \\
\text { drops } 0.5 \%\end{array}$ & 50 & 49.68 & 50.50 & 99.35 & 101 \\
\hline
\end{tabular}

*Average of three determinations

\section{Comparison of the method with other methods}

Table (7) gives the results obtained by application of proposed method and literature method for the determination of pp hydrochloride in pharmaceutical preparations.

Table (7): Comparison of the present method with other method

\begin{tabular}{|c|c|c|}
\hline Analytical parameter & Present method & $\begin{array}{c}3,5-\mathrm{DNS} \\
\text { method }^{(14)}\end{array}$ \\
\hline$\lambda_{\max }(\mathrm{nm})$ & 530 & 410 \\
\hline Temp. $\left({ }^{\circ} \mathrm{C}\right)$ & R.T & R.T \\
\hline $\mathrm{pH}$ & Without & Basic medium \\
\hline Development time $(\mathrm{min})$ & 5 & 5 \\
\hline Stability period $\left(\mathrm{min}^{-1}\right.$ & 115 & 8660 \\
\hline Molar absorptivity $\mathrm{mol}^{-1} . \mathrm{cm}^{-1}$ & 14320 & $0.5-20$ \\
\hline Linearity $\left(\mu \mathrm{g} . \mathrm{ml}^{-1}\right)$ & $0.5-10$ & 99.80 \\
\hline Recovery $(\%)$ & 99.72 & $<0.5$ \\
\hline RSD $(\%)$ & $<1.5$ & eye drops \\
\hline Analytical application & eye drops & \\
\hline
\end{tabular}

From the results shown in table (7) there is similarity in recovery, both methods done in room temperature in addition the present method is more sensitive, without buffer solution, simple and does not require solvent extraction.

\section{CONCLUSION}

A simple, precise and sensitive spectrophotometric method has been developed for the determination of $\mathrm{pp}$ based on proton transfer reaction between $\mathrm{pp}$ and ARS reagent to form colored product. The method doesn't involve the use of complicated sample preparation or buffer solutions. Low value of standard deviation shows that the method is precise, whereas high percentage of recovery shows that the method is free from interference of the excipients used in the formulations. The method was successfully applied for the determination of $\mathrm{pp}$ in pharmaceutical formulation as eye drops and the results were in good agreement with the standard addition procedure . 


\section{REFERENCES}

1) "Dictionary of Organic Compounds", Vol. V, $5^{\text {th }}$ edn., (1982), Chapman and Hall, New York, pp. 4622, 5237.

2) http://health.yahoo.com/drug/d00704al,2001.

3) http://health.yeahoo.com/drug/d0331791,2001.

4) http://www.n/m.nih.gov/medline plus/drug inf/updi/202460.html, 2005.

5) M.Q. Al-Abachi and Hind Al-Ward, (2002), National J. Chem., 6, 221-230.

6) J.R. Rocha, C.X. Galhardo, M.A. Natividade and J.C. Masini, (2002), J. AOAC Int., 85, 4, 875-878.

7) E.H. El-Mossalamy, (2004), Spectrochimica Acta Part A: Molecular and Biomolecular Spectroscopy, 60, 5, 1161-1167.

8) Theia'a N. Al-Sabha , (2010), Pak .J. Anal. Environ. Chem., 11,1,1-7.

9) M. Yamaguchi, H. Monji, I. Aoki and T. Yashiki, (1994), J. Chromatog. B: Biomed. Sci. and Appl., 661, 1, 93-99.

10) V. Vuma and I. Kanfer, (1996), J. Chromag. B: Biomed. Sci. and Appl., 678, 2, 245-252.

11) A Martin, E. Garcia, A. Garcia and C. Barbas, (2002), J. Pharm. and Biomed. Anal., 29, 4, 701-714.

12) R. Delevie, (1997), "Principle of Quantitative Chemical Analysis", McGraw-Hill, New York, p. 498.

13) O.V. Khranina, F.P. Chernyakovskii and G.S. Denisov, (1987), J. Mol. Struct., 177, 309-315; Chem. Abst., (1989), 111, 5, 38746w.

14) AL-Neaimy U.I.S, Ph.D. Thesis, University of Mosul , (2006). 